\title{
Healing our Brokenness: A pastoral care approach
}

\author{
Xolisa Jibiliza \\ Centre for Theology and Religion \\ University of Fort Hare \\ 1 King Williamstown Rd \\ Alice, 5700, South Africa \\ E-mail: xjibiliza@yahoo.com \\ Prof. S.R. Kumalo \\ Head of Department Practical Theology \\ University of KwaZulu Natal and \\ Chairperson of the SA Practical Theology Association \\ South Africa
}

Doi: https://doi.org/10.46222/pharosjot.102.216

\begin{abstract}
Pastors, priests and ministers of congregations and all people of faith, are called to communicate the faithfulness and care of the Creator to the adherents of the faith. This needs to be carried out in the contexts in which communities live and through the ways people experience challenges in life and seek healing. This research paper sought to acknowledge the healing of our brokenness using a pastoral care approach as the lenses through which to explore the issues. The paper revealed some themes such as a definition of what pastoral care includes, what the researcher thinks about pastoral care and the methodology that the researcher has used. Furthermore, this paper sought to give an impact of the pastoral care in the lives of church members who are experiencing a sense of brokenness. Community pastoral care is required to integrate the revelation of the Kingdom of God and His grace and blessings, as well as the prospect of a solid association with Him when it comes to being whole. Such a linkage will serve to transform the life of the people in a community under duress. For healing to take its course, forgiveness has to be effected and then a reconciliation can then be the enhancer of healing. Grounds therefore need to open for people to speak openly with no biases being the stumbling blocks for them in revealing their feelings and frustrations. The predominant theological understanding of interpersonal forgiveness, as it is portrayed in Christian Scriptures and the teachings of Jesus, is that interpersonal and divine forgiveness are inextricably related. Theologically, one cannot consider the forgiveness of another person outside the context of God's forgiveness. Brokenness is part of our lives because we are born into sin. This paper also reveals to a limited extent the impacts of the spiritual discipline of prayer, pastoral care in a process of healing, preaching as counseling tool for healing, and healing of total depravity.
\end{abstract}

Keywords: Pastoral care, healing, brokenness, spiritual discipline, total depravity.

\section{Introduction}

Pastoral care is always a very active and all-inclusive approach and care for individuals and also groups of people in what are socially constructed communities (Louw, 2005). The core focus is however individuals (Louw, 1998). People in a community identify with each other and share rituals and culture which strengthen their identity as a group with common views on life (Gilchrist \& Taylor, 2011). Pastoral care involves sustaining others through continued difficulty or immediate need. It means that pastors need to help people in the journey of healing and attaining wholeness. 
considering the process of reconciliation with God, with one's self and also with others (Gerkin, 1997). Pastors who care offer guidance about other resources which they may not have and enable different perspectives to assist in care. Thus pastoral care needs to embrace societal and cultural direction and the pastor is considered to be the guide and leader (Gerkin, 1997). The pastor provides spiritual leadership to members of his or her church and offer care and counselling to church members and assist them in predicaments impacting their spiritual lives.

\section{Healing}

Healing is to restore one's health or soundness; to cure, also is to experience relief from emotional distress. Healing is thus a profound area of both human experience and belief, that of true self living and that of faith, where one speaks out one's inner-most depths. One seeking healing considers their life and do not attempt to force themselves into any direct correlation with others yet staying alert for areas of convergence in situations (Chaudhari, 2012: 453). Furthermore, when a person wants to live he begins to heal himself by accepting the healing before the healer comes to him.

\section{Brokenness}

Brokenness literally means the experience of a 'sense of darkness' in one's life. The book of Job is an example mostly reflecting as the story of someone who experienced the darkness of human experiences. Ham (2016: 240) has argued that the book of Job is devoted to reflecting the darker experiences of human suffering and comprises mostly of a sense of brokenness. Brokenness is the pain that is cause by what a person has experienced in the past and which has left him or her devastated. This can for example, be caused by the death of a loved one and deep hurt which then results. Furthermore, those who experience brokenness teach us something about the depth to which a person of great faith may go in voicing their pain. During this critical juncture, it is rare for a person to express that he is suffering but he or she is nonetheless still struggling and needs pastoral care.

\section{Theoretical framework}

This paper seeks to use a pastoral care approach as the lens through which to look at the issue of healing brokenness and the trauma of the present and the past. The pastoral care approach is that aspect of the ministry of the church which is concerned with the well-being of the individual and the community at large (Campbell, 1987: 188).

This research study was guided by Gerkin's shepherding method of pastoral care. This theory or method was deemed apt for this research as it is relies to a triangular shape in showing its function. Gerkin's (1997: 23) biblical traditional method of shepherding thus involves the trialogical structure of priests, prophets, wise men and women and is based on an understanding of the way in which these individuals collectively took authority in shepherding God's people in the Old Testament period. Gerkin's approach focuses both on individual and family needs. He points out that pastoral care involves both the care of the Christian community and the care of persons: individually, in families, and in large group relationship (1997: 113). This is in contrast to the psychotherapeutic pastoral care model common which is used in America and Western pastoral care settings. Gerkin's approach to pastoral care has been advanced by many African scholars. For example, Mucherera argued that therapy or counseling, as taught in the West, will not always suffice in indigenous contexts since these theories tend to promote and focus on individuality, autonomy and independence (2006; 2017). 
This caring method of shepherding is helpful because it provides an integrated approach to healing that was en-culturated in the African belief system and culture, which views healing as taking place within the community and not in any way in isolation. Gerkin's (1997) illustrated his point by stating that representation of Jesus as "the good shepherd who knows his sheep and is known by his sheep", has highlighted a "meaningful, normative portrait of the pastor of God's people" (Gerkin, 1997). Gerkin's method of pastoral care was considered for this research study because it is all encompassing and addresses individual and family problems within the context of lived experiences. This is an ideal method of helping people in need of pastoral care/therapy, and this includes for example mothers affected by child defilement by a church leader.

\section{Methodology}

Both primary and secondary data were be collected for the study. Primary data refers to what was extracted from the Holy Bible. Secondary data is defined as data that has already been produced by others (Matthews \& Ross, 2010). In this study, secondary data was collected by means of an literature review of the theoretical construct of pastoral care. The review describes the theoretical perspectives and reviews previous research findings. The review was conducted using peerreviewed journal articles and academic books as well as Google Scholar. Mouton (2008: 70) stresses that whereas quantitative research refers to counts and measures of things, qualitative research refers to meanings, concepts, definitions, characteristics, metaphors, symbols, and descriptions of things which a literature study can unpack to an extent.

\section{Spiritual discipline of prayer}

In this partly spiritual discipline on healing the researcher sought to explore the one key aspect of the spiritual disciplines which is prayer through the quandary of healing during the coronavirus era that the world is engulfed in The are many biblical references that teach Christians on the notion of the spiritual discipline of prayer as it is central to Christian spirituality. It is the way to invite the presence of Jesus, without denying the omnipresence of the Triune God, moreover it is the means to communicate with God the Father as Jesus did in the Our Father prayer. Therefore prayers relate closely to specific statuses and needs where someone who prays appeals to God. Prayer is in essence a privilege for the Christian as he or she gets to communicate with God. Foster (2012) emphasizes the spiritual discipline of prayers and states that prayer is so central to Christians:

Of all the spiritual disciplines, prayer is the most central because it ushers us into perpetual communion with the Father. Meditation introduces us to the inner life, fasting is an accompanying means, study transforms our minds, but it is the discipline of prayer that brings us into the deepest and highest work of the human spirit.

Prayer as a discipline is then the means of getting close to God for the healing of the soul. Most times prayer is the communication by which a person who is appealing to God has a conversation with Him. Lombaard, (2018: 109) argued that prayer is a response only in the sense that one finds oneself engaged in it; one finds oneself, somehow, having prayed, or praying - again in this sense only, that one finds oneself at prayer; one also finds oneself as having been led into this act of deep faith in communion with God.

Moses spoke with God directly in the Mountain of Horeb (Deuteronomy 5). The retelling of history in Deuteronomy 5, shapes the new identity of Christianity that is embedded on the values of prayer. We must re-imagine the Sinai events of communicating with God, and from that, then begin to re-imagine the Christian character that we are called to live as pastors. At times Moses 
fulfilled a range of leadership roles ranging from inter alia, faithful shepherd, negotiator, intercessor, hero, tactical genius, strategist, militarist, judge, mentor, motivator, provider and guide. We as pastors need to also adopt this approach. We too need to co-ordinate the efforts of specialists and integrated knowledge for the benefit of the people we serve as pastoral carers. We are required to an extent to mobilize the people and drive them towards a common objective in serving God. (Jansen van Rensburg \& Nicolaides, 2015). The call to faith in God and in God alone is more active when the person that has been called is communicating with God through prayer. The grace on how this faith ought to be lived arrives through prayer.

Those who are experiencing unanswered prayers need to reconcile these experiences with their religious beliefs; otherwise, they might face issues of spiritual struggle, which negatively affects their physical or mental well-being. (Chou \& Good, 2019: 316).

\section{Pastoral care in a process of healing}

"Where there is no counsel of families the people fall, but in the multitude of counselors there is safety" (Proverbs 11:14). Pastoral counseling of families will continue to be inadequate as long as it starts at treating the symptoms rather than the cause of the disease one faces. It is also my contention that we should begin at the very root of the problem. Having critically analyzed the issue of moral decay and the damage relationships, the researcher will also continue to bring forth the intrinsic focal point of departure with regards to pastoral care. The brokenness as identified during the coronavirus due to many deaths of people we know, families, and friends, show us that. as the church is indeed playing the vital role in offering comfort to people throughout (Dames, 2020). The same Church which played the vital role to comfort people has been accused of being a super-spreader of the virus in many instances globally. Locally, as it happened, a funeral in Port Elizabeth in 2020 was identified as the place from which the Covid-19 virus spread. The pastoral care that was needed by the people that were grieving for the loss of their loved ones comes from the church and so many have hope in pastors and the church in spite of the attacks against the church.

One of the symbols of an empty Church is to not have people to talk to, to be able listen to what a person feels and goes through in a process of utter frustration without pastoral support. Mwaura as cited in Waruta et al (200: 84-85) argued that we have seen healing covers all aspects of disorder which affects all levels of being. As such pastoral care in the Church should be holistic, and attending to all levels of human physical (temporal) moral and spiritual need. Good pastoral care does not ignore the physical needs of a person or community. It is from this position that the researcher also feel strongly that God is concerned with human happiness, which entails health, material benefits, peace and salvation. God gave humanity dominion over all creation (Genesis $1: 23 ; 5: 3)$. God also destined humanity to live in society and to organize it and everything for the common good. However, selfishness and greediness has prevented people from properly using the resources at their disposal and has prompted them to abuse human rights of individuals and groups, thereby impeding development and creating unjust and horrific situations. Mwaura (2000: 85) stated that the Church in its role as the 'shepherd' of God's flock must address this situation by alleviating suffering and enabling the realization of God's Kingdom. The administration of healing that will resolve harmony in the lives of people, whether it be individual, community and or in the environment is therefore essential. The affirmation is made by Jesus Christ in the gospel of John 4: 16 when he said his mission is to "preach the good news to the poor....proclaim the release of the captives, recovering the sight of the blind and to set the liberty to those who are oppressed". Therefore this includes the healing of the mind for those who are 'mind' oppressed. 
It is the prerogative of the Church that pastoral work of the Church to be seen in terms of healing, guiding, sustaining and reconciling the people of God. There needs to be a strong Christian ethics as espoused in the Christian faith and a solid servant leadership motivation based on deep spirituality which is required to link with what pastoral work does in a manner which allows for the desired principles, standards, and procedures for actions and a set of divinely inspired virtues to be fulfilled (Nicolaides, 2020). Furthermore according to the bible, God is the ultimate source of all pastoral care and this care involves deliverance from all types of bondage such as social, political and economic (Exodus 3:7-9). In the book of Exodus 15: 26 we see the restoration of personal health and God is portrayed as a forgiving God who is always ready to accept repentant individuals and nations (Hosea 11: 8-11).

The researcher noted that the Hebrew words for peace, salvation and cure means restoration of wholeness. Eventually, it is God who restores this wholeness and that is the Shalom aspect. It is therefore that through Jesus who is both the Savior and healer, that people are redeemed to God through the ministry of Jesus, his death and resurrection. Furthermore, repentance paves the way for God's saving action in individuals, groups and communities.

In the Gospels Jesus continues the work of healing by restoring what is broken, healing what is fragmented through the healing community, which is the Church. Jesus came to save humanity from sinfulness, suffering sickness and death, his depiction from the Synoptic Gospels as one curing all kinds of disease and illness (Matthew 9:35) is evident in many places. Jesus' caring for the sick involves bringing them back to life physically and psychologically. His will is that humanity should not suffer and he never even inferred that a sufferer should remain ill to acquire courage or learn patience (Matthew 8: 2-3; Mark 1: 4-5; Luke 5: 12-13). He was compassionate, and understanding, and his healing was holistically directed at the restoration of the entire personality of an ill person, not just the body.

The Church cannot be indifferent to this distressing problem, which involves so many of the Church's members, and the problem must be faced with resolution and without delay. The Church, Mother and Teacher, seeks the welfare and happiness of her members and when they are broken for whatever reason the Church suffers and seeks to provide a remedy, and offers those hurting people pastoral guidance in complete fidelity to Christ's teachings.

When individuals in an irregular situation return to Christian practices, it is necessary to welcome $\mathrm{him} /$ her to the community of God with charity and kindness, helping them to clarify their concrete status by means of enlightenment and enlightening pastoral care. A fraternal and evangelical welcome towards those who have lost contact with the Church is of great importance. Thus, it is the first step required to integrate them into Christian practice. It is necessary to introduce them to listening to the word of God and to prayer. They also need to be involved in the charitable works of the Christian community for the poor and needy, and awaken the spirit of repentance by acts of penance that prepare their hearts to accept God's grace which is poured out upon them as they atone (Nicolaides, 2016).

\section{Preaching as a counseling tool for healing}

This section of preaching as a counseling tool for healing is based on the text from Matthew 4: 23 when Jesus Christ went throughout Galilee, teaching in the Synagogue and proclaiming the good news of the kingdom and curing every disease and every sickness among the people. The researcher opines that people cannot be presumptuous about healing and also may not understand the hindrances to healing or why after much faithful prayer, some people are not healed. What we believe in, is that Jesus heals today and that our faith needs to work in co- 
operation with the Holy Spirit. Therefore, we as Christians must continue to trust Jesus as our wounded healer, whether our prayers seem to be effective or not.

We must see the link between preaching and healing that compels us to say with the Father whose Son was wounded in order for us to be healed, that thus, we are healed by his wounds (Isaiah 53). The best way of healing is to preach the gospel with the help of God's Spirit the 'Comforter' who leads us to proclaim the gospel with joy and gives us fruitful results which encourage us to always be joyful for the Gospel of healing and transformation in our lives. Our pastoral care must manifest in an African context and needs to be well-versed in Ubuntu where the notion of collectivism is crucial and this is also the role of the entire church (Ekklesia) of God (Nicolaides, 2010). The Holy Spirit encourages us not to look depressed or as if we just came back from a comforting people from the loss of their loved ones, but allows us to preach with warmth, to be modest and to be ecstatic in our gestures.

Hart (2016: 23) stated that we must look to Jesus who is tuned in to peoples' needs. He forgave those who needed forgiveness; He calmed their fears and healed their wounds. Jesus cleansed lepers, gave sight to the blind, healed the deaf and mute, and drove out demons. As we are followers of Jesus we must follow in His footsteps and always strive to do what Jesus did in response to the healing ministry. In fact in terms of the African philosophy of Ubuntu we need to care for others since they exist because of us and vice versa so that 'a person is a person through other people' (Nicolaides, 2005).

Hart (2016: 21) stated that we need to be a source of healing, empowerment, encouragement and liberation for people. Furthermore, he stated that Pope Francis wants us to become apostles of mercy, touching and conciliatory towards their wounds, and to encourage our congregants not to remain behind closed doors because of their fears. As we stare out to the congregation, we see those who are heartbroken, anxious, hapless and hopeless, therefore our proclamation should touch those souls that are in need. Healing is a sign gift, which enables one to function as an instrument of God's healing grace in the lives of hurting people. During this Covid19 pandemic era the Church is more challenged in terms of conducting the healing services as the way to comfort, counsel and heal people. This is due to the South Africa President Cyril Ramaphosa in ways logically prohibiting the religious gatherings as they are viewed as possible super spreader events of the of coronavirus. Nonetheless Church remains an important role-player in caring for society.

\section{Healing of total depravity}

The healing of total depravity is the healing of body, emotions and mind. Each of these three things require healing. The researcher refers to this as the tripartite healing of a person. The bible stresses that "Jesus consistently related His healing activity to the emergence of the kingdom of God." Healing happens when we proclaim the kingdom of God because it counteracts all sin, evil and death. The psalmist, King David, states it well: "Bless the Lord, my soul; do not forget all the gifts of God, who pardons all your sins, heals all your ills" (Psalm 103:2-3). The gift of healing includes miraculous healing of body, mind and emotions (Ellens, 1984). Thus, healing has been labeled in various ways: faith healing, divine healing, Christian healing and spiritual healing. In this section the researcher discusses these aspects of healing, starting with faith healing, followed by divine healing, Christian healing and finally spiritual healing.

\section{Faith healing}

The term/notion "faith healing" is occasionally used in connection with Christian Science, though its adherents maintain its practice of healing is methodical and does not rest on faith alone, but 
also on an intimate understanding of God's law. Faith healing is the practice of prayer and signs (such as laying on of hands) that are supposed to elicit divine intervention in spiritual and physical healing, especially in Christian practices. Jesus told his followers to heal the sick and stated that signs such as healing are indications of faith. Jesus told his supporters to "cure sick people, raise up dead persons, make lepers clean, expel demons. You received free, give free".(Matthew 10:8; Mark 16:17-18).

The faith that those who need healing has shaped their lives to be what they are in their present lives, irrespective of the interventions of the Church, they could seek and find, lament to their creator God. In faith they believe they have been healed but whilst they believe that, they feel it is still essential for people in troubled situations to have mentors who will guide and nurture them (Lartey, 2006).

Pastoral ministry comprises 'shepherding the flock' of believers: .

...Shepherding involves protection, tending to needs, strengthening the weak, encouragement, feeding the flock, making provision, shielding, refreshing, restoring, leading by example to move people on in their pursuit of holiness, comforting, guiding (Ps 78: 52; 23).

Chiroma (2020: 1) stated that faith is the total dependence that is coming from belief, trust and fortitude. It is the ability to keep believing and holding on in the middle of problematic circumstances. Faith is an active trust in someone or something that can be trusted. Therefore faith healing is meant for those who search for healing through their faith and only trust that healing comes from the Divine being. They believe in the unseen God whose mighty deeds are seen by people. Hospital workers and doctors often refer ill persons to the services of the growing healing ministries of Pentecostal churches because of their growing standings for faith-healing and cures (Asamoah-Gyadu, 2007:44). Chiroma (2020: 5) also argued that the healing narratives and testimonies were the discourses about a patient's faith, the patient's family faith, and the role of prayers, pastors and priests. What is most important in a healing process is the faith of the person who is conducting the healing, the patient's faith and his or her family faith. These are vital for the patient to be healed. The nature of faith healing testimonies and narratives provide a sincere space for patients to reconstruct their own experiences of illness and to renegotiate their link to the healing site (Chiroma, 2020: 5), Nicolaides,(2016) asserts that millions of people travel annually to religious pilgrimage sites for healing based on strong faith. When healing is done therefore those people who have been healed should provide testimonies of their healing. By doing so is to give a testimony on the work of a loving God in their lives.

Faith healing is controversial in some cases and is subject to distortion and abuse as are other practices of religion and science. Perhaps the most important hindrance that has needed to be overcome when speaking of faith healing is the fundamental disbelief of the modern scholar towards anything so thoroughly marked by the supernatural (Buller, 2002: 75). Healing comes from God through Jesus Christ and the Holy Spirit works in the persons involved, both the healer and the patient.

\section{Christian Healing}

Christian healing is a process that involves the totality of our being body, mind, emotion and our social context and that directs us toward becoming the person God is calling to be at every stage of our living and dying. Whenever we are truly open to God some kind of healing takes place, because God yearns to bring us to wholeness. Matthew 10:1 states: "And he called to him his 
twelve disciples and gave them authority over unclean spirits, to cast them out, and to heal every disease and every affliction."

Through prayer and the laying of hands, through confession, anointing, the sacraments and other means of grace, Jesus meets us in our brokenness and pain and there loves, transforms, forgives, redeems, resurrects and heals us. Jesus does this in God's way, in God's time and according to God's loving purpose for each person. Magezi and Magezi state:

\begin{abstract}
The metaphor of the New Adam (Jesus Christ) as a suffering servant who truly identifies with Christians in their various contextual suffering was established as both healing and empowering for believers. In the incarnation, God in Christ truly identifies with humanity as the New Adam and he knows what it is to suffer as a human being; hence, there is no human experience that is foreign to him. He (Christ) knows what it is to be human in all aspects of life, but he did not commit sin. African Christians should have confidence that the Godman, Jesus Christ, has complete solidarity with them in their suffering, and he is able to bear with them in their suffering as the faithful and merciful high priest. (Magezi \& Magezi, 2016)
\end{abstract}

The researcher has witnessed that Christian healing is not something that is magical. It is not manipulating God to do what we want, but it is surrendering to God's healing work in us, to us and upon to us. Christian faith for healing is not a prediction of what God will do, but it is simple trust that God loves us and is at work in us already. Christian healing is not to be sought as a spiritual thrill for the healer or a person healed, but it is always to grow as a Christian. Christian healing is not proof of our faith or holiness but it is a sign of God's love. Isaiah 38:15-16 tells us to call on God for physical healing: "What shall I say? For he has spoken to me, and he himself has done it. I walk slowly all my years because of the bitterness of my soul. O Lord, by these things men live, and in all these is the life of my spirit. Oh restore me to health and make me live!"

\title{
Spiritual healing
}

Spiritual healing is when energy is transmitted to the person who needs it. The treatment work of the body, mind and spirit which is seen as one unit that must harmonize for good health. If a separate healer is involved, the healer will place the hand on the person being treated to channel the energy from the Higher Source who is God. The spiritual healing can help mental and emotional problems and physical conditions. Jeremiah 17:14 tells us: "Heal me, O Lord, and I shall be healed; save me, and I shall be saved, for you are my praise."

The channeling of healing energy from its spiritual source to someone who needs it is called spiritual healing. The channel is usually a person, whom we call a healer and the healing energy and the healing energy is usually transferred to the patient through the healer's hands. The healing does not come from the healer, but it comes through him. On the other hand, you do not need a healer to take an advantage of spiritual healing. The researcher alluded to the fact that a person can pray a full treatment of prayer and healing be found elsewhere. 1 Peter 2:24 informs us that: "He himself bore our sins in his body on the tree, that we might die to sin and live to righteousness. By his wounds you have been healed."

The word spiritual thus refers to the divine nature of the energy, which the healers agree comes from one external, invisible intelligent source. The healing energy from the source is available to all. Healers see the body, mind and spirit as one interdependent unit and believe all three must work in harmony to maintain positive health. Any problem, whether in a body, mind and spirit needs a power of healing to restore the balance of the whole person. It is alleged that sickness often starts from mind or at the deeper level of the spirit and it often here that healing begins. 
Psalm 41:3 explains "The Lord sustains him on his sickbed; in his illness you restore him to full health."

Spirituality involves the recognition and acceptance of a God beyond our own intelligence and with whom we can have a relationship. Our God can provide an experience of inspiration, joy, security, peace of mind and guidance that goes beyond what is possible in the absence of the conviction that such a power indeed exists.

\section{Divine healing}

The term is sometimes used in reference to the belief of some Christians who hold that God who heals people through the power of the Holy Spirit, often involves the "laying of hands". Those who hold to this belief do not usually use the term faith healing in reference to the practice, and that expression is more often used descriptively by reporters outside of the faith movement in reference to the belief and practice. Pentecostals and Charismatics who believe in supernatural healing generally do not excuse the practice of withholding medical treatment in those cases when physicians determine that the suppression of such treatments would be harmful to the patient's health.

Healing from different and various contexts are determined by the socialization as well as the culture of the specific contexts. Wright (1985:20) argued that the more he responds to God's love in Christ, the more whole he becomes, the more sensitive he becomes too and paradoxically the more he shall suffer. God sent His son to heal us in three ways, spiritual, emotional and psychological. Matthew 9:35 informs us: "And Jesus went throughout all the cities and villages, teaching in their synagogues and proclaiming the gospel of the kingdom and healing every disease and every affliction." In mentioning the various forms of healing, most Christians agree that we should be followers of Jesus Christ; however, all too often we miss a major part of the ministry of Jesus. Most of people missing are those who misunderstood healing, moreover others missed it because it is abused by those who would seek their own fame or riches by it. Jesus in his ministry, administered the ministry of healing to the whole person body, soul and spirit. Magezi (2007) contends that in pastoral care, Jesus and salvation are, dominant 'pieces of the puzzle in pursuit of healing' and that the story of salvation is connected to the story of human /struggle, agony and suffering' (Magezi 2007:757).

Since we ought to follow Jesus, thus, let us throw aside the misconceptions and abuse to see what the Word says.

Firstly, the word says that Jesus, being God, laid aside his divine attributes in becoming the ManGod upon the earth, the Theanthropos. Christ took upon himself the form of a suffering servant and was made in the likeness of men, and being found in the fashion as a man, he humbled himself, and became unto death, even the death of the cross (Philippians 2:5-8). The death of the cross was to humiliate him, and also to shame him, but the symbol of shaming and humiliating him became the symbol of victory for the healing of our total depravity. Also in Deuteronomy 7:15 we find: "And the Lord will take away from you all sickness, and none of the evil diseases of Egypt, which you knew, will he inflict on you, but he will lay them on all who hate you."

Secondly, the word emphasized that Jesus, being human (not denying his deity) was obedient. He was obedient in being baptized (immersed). Therefore, being without sin he gave himself to be baptized by a sinful person as a lesson for us to be baptized in the name of the Father, Son and Holy Spirit. 
Thirdly, at his baptism, he was baptized by the Holy Spirit. During his baptism the heavens opened up and the voice from God the father affirmed that He is his Son and must be heard by the world and the Spirit of God came in a form of a dove and sat upon him (Matthew 3:16).

Jesus Christ is God himself, who assumed our human manner of existence as the New Adam and fulfilled the prophecy of the suffering servant mentioned in Isaiah 53 (Olagunju 2013). He underwent sufferings on our behalf so that he could bring an alienated people back into eternal fellowship with God through atonement (Nicolaides, 2014). Luke 8:50 reminds us that we need to believe: "But Jesus on hearing this answered him, "Do not fear; only believe, and she will be well."

Healing for Jesus Christ was a major part of his ministry, because the majority of people that Jesus healed were the poor and marginalized people. The researcher notes that healing includes sickness, diseases, demonic activity, mental disturbance and abnormalities (Matthew 4:24).

\section{Conclusion and Recommendations}

We as Christians, must take care of the healing ministry to save our land. We must not forget that we are the part of Christ's body which is the Church that is embedded upon a healing ministry. There are close links between evangelism and Community Pastoral Care and as such healing the bodies of people and saving their souls are linked issues to consider. God's saving grace encompasses all parts of our lives and so pastoral care needs to embrace one's existence totally so care must be is open to acting towards all needs as far as is possible.

The world is bleeding due to many illnesses that have wounded our people and continue to do so. Coronavirus is another enemy that we face and that makes our people wounded humans. The Church has the responsibility of healing the world that is wounded. The researcher recommends that pastoral care should be a route which must continue to be followed by the church. Pastoral care in the church should not be seen as synonymous with all the tasks usually assigned with the minister or pastor. The Church is the place that has a number of faithful believers and those people that are in it belong to the Church, and it is therefore imperative for them to partake in the healing process of parts of their body which in this case become affected and inflicted by the Covid19 within the church and in the greater community.

The researcher also recommends that the church should be seen as a redemptive society because Jesus formed the Church to be a redemptive society in the world, not isolated from the world but devoted to the service in the world. The idea of a ministering church, asserting the vocational identity of every Christian as a servant and defining the pattern of participation is true pastoral care. It is rooted in the scriptures and is highly relevant in the contemporary situation we face. Pastors need to be able to adjust their message of hope to what is happening in and around the whole community of faith.

For healing to take its course on the path to forgiveness has to be effected and then a reconciliation can then be the enhancer of healing. Grounds therefore need to open for people to speak openly with no biases being the stumbling blocks for them revealing their feelings and frustrations. The predominant theological understanding of interpersonal forgiveness, as it is portrayed in Christian Scriptures and the teachings of Jesus is that interpersonal and divine forgiveness are inextricably related. Theologically, one cannot consider the forgiveness of another person outside the context of God's forgiveness. Brokenness is part of our lives because we are born into sin. But our brokenness is not only through sin but all the impediments in our lives that keep us from fully experiencing God's love, which is unceasing in spite of human failings. In this penetrating reflection, we should be leading through the experiences of brokenness in all areas of life in our daily existence, in the Church, and in our world. The Church should guide us to an 
understanding of the effects of our brokenness on us and the community of humankind. Moreover, we encounter the risen Lord who brings us to our own resurrection through death due to sin and in the living presence in the Eucharist. Therefore, the Church should be the healing community that made up of a number of workable aspects. Church leaders and leaders from faith traditions must continue to make a massive difference to the health and well-being of their communities as they respond to the Covid19 and other crises that may arise. Pastors need to offer psychosocial support to families and the greater community and provide spiritual and other support where possible. Because of their faith in God, pastors need to be the people, who keep their heads when all about you are losing theirs. We should be a role-model to the parishioners on how to respond in distressing times. We need to offer hope and confidence in God through this tough time. Anxiety is a psychological, emotional, and spiritual battle many of our people face and we must comfort them and try to help them obtain needed support where there is need.

\section{References}

Asamoah-Gyadu, J.K. (2007). 'On the "mountain" of the Lord: Healing pilgrimages in Ghanaian Christianity', Exchange, 36 (1), 65-86. [Available online at https://doi.org/10.1163/157254307X159425]

Babbie, E. (2010). The practice of social research, USA: Learning Customer \& Sales Support.

Bless, C., Higson-Smith, C. \& Sithole, S.L. (2014). Fundamentals of Social Research Methods: An African Perspective, Cape Town: Juta.

New International Version Bible. Bible Society: Port Elizabeth.

Buller, C.A. (2002). Healing Hope: Physical Healing and Resurrection Hope in a Postmodern Context, The Salvation Army Ethics Centre,, 10(2), 74-92

Campbell, V.A. (1987). A Dictionary of Pastoral Care, London: British Library Cataloguing.

Chiroma, N.H. (2020). 'The therapeutic and integrative significance of faith in the African quest for healing and wholeness', HTS Teologiese Studies/Theological Studies, 76 (2), [Available online at https://doi.org/10.4102/hts.v76i2.6014]

Chou, H. \& Good, K. (2019). Impacts of perceptions of parents on individuals' reactions to unanswered prayers, Journal of Spirituality in Mental Health,21(4), 309-321. [Available online at https://doi.org/10.1080/19349637.2018.1510752] (Access Date 23/06/2021).

Dames, G.E. (2020). Biblical vistas of brokenness and wholeness in a time such as the coronavirus pandemic, HTS Teologiese Studies/Theological Studies, 76(4).

Ellens, J. H. (1984). Toward a theology of illness, Journal of Psychology and Christianity 3 (Winter): 61-73.

Forster, R. (2012). Celebration of Spiritual Discipline: The path way growth study guide edition, London: Hodder \& Stoughton.

Fowler, J.W. (1983). 'Practical theology and the shaping of Christian lives', in D.S. Browning (ed.), Pastoral theology: The emerging field in theology, church and world, 148-166, Harper and Row: San Francisco, CA.

Gerkin, C.V. (1997). An introduction to Pastoral Care, Nashville: Abington Press. 
Gilchrist, A. \& Taylor, M. (2011). The Short Guide to Community Development, Bristol: Th e Policy Press.

Hart, R. (2016). Preaching and Healing: Best form of healing is to preach with a spirit of joy, Wisconsin: Word of God.

Haudhari, P. Freedom for Relationship: An Initial Exploration of the Theology of Zizioulas and the Psychoanalytic Insights of Winnicott in Dialogue. Pastoral Psychology, 62, 451-460.

Jansen van Rensburg, M. \& Nicolaides, A. (2015). An analysis of theological and strategic management perspectives of Moses as a leader, Pharos Journal of Theology, 96.

Lartey, E.Y. (2006). Pastoral Theology in an Intercultural World, Cleveland, Ohio: Pilgrim Press.

Lombaard, C. (2018). Prayer in the Old Testament as spiritual wisdom for today (Online) Acta Theologica, 38(1), 99-114 [Available online at http://dx.doi.org/10.18820/23099089/actat.v38i1.6] (Access Date 22/06/2021).

Louw, D. (2005). Cura Vitae: Illness and the healing of life, Wellington: Lux Verbi.

Louw, D. (1998). A Pastoral Hermeneutic of Care and Encounter, Wellington: Lux Verbi.

Magezi, V. \& Magezi, C. (2016). Pastoral care and healing in Africa: Towards an Adamic Christological practical theology imagination for pastoral healing. HTS Theological Studies, 72(2), $1-12$.

Magezi, V. (2007). 'Pastoral counseling: Towards a diagnostic and interpretational approach in Africa', Die Skriflig, 41(4), 655-672. [Available online at http://dx.doi.org/10.4102/ids.v41i4.325]

Mason, J. (2007). Qualitative Researching, London: SAGE.

Matthews, B. \& Ross, L. (2010). Research Methods, Pearson Longman: London.

Mouton, J. (2005). How to succeed in your Master`s and Doctoral Studies, PTA: Van Schaik.

Mucherera, T.N. (2006). Pastoral Formation of Counselors in Intercultural Societies, American Journal of Pastoral Counseling, 8(3-4), 99-111.

Mucherera, T.N. \& Lartey, E.Y. (2017). Pastoral Care, Health, Healing, and Wholeness in African Contexts: Methodology, Context, and Issues, Häftad Engelska

Nicolaides, A. (2020).Contemplating Christian ethics and spirituality for sound leadership in organisations, Pharos Journal of Theology, 101: a.37

Nicolaides, A. (2016). Marian Tourism: Eastern Orthodox and Roman Catholic pilgrimage. African Journal of Hospitality, Tourism and Leisure, 5(4).

Nicolaides, A. (2014). The Seventh Ecumenical Council and the veneration of icons in Orthodoxy, Acta Theologica, 34(2).

Nicolaides, A. (2010). 'The Laos tou Theou - an orthodox view of the "people of God"', HTS Teologiese Studies/Theological Studies, 66(1). 
Nicolaides, A. (2005). 'Ubuntu promoting ethical business conducts in African Society. Orthodox and the great social and economic problems of Africa: The contribution of the great monotheistic to their solution', paper presented at the International Interparliamentary Assembly on Orthodoxy Conference, University of Johannesburg, 02 December.

Olagunju, J. (2013). 'Sin, sickness, and salvation: A holistic approach to healing', Ogbomoso Journal of Theology, 18(2), 112-121.

Waruta, D.W. \& Kinota, H.W. (eds.) (2000). Pastoral Care in African Christianity- Challenging Essays in Pastoral Theology, Nairobi: Action Publishers.

Wright, F. (1985). The pastoral nature of healing, London: SCM Press LTD. 